\title{
PROGRAM FOR THE APPLICATION OF GENETIC TRANSFORMATION FOR CROP IMPROVEMENT IN THE SEMI-ARID TROPICS
}

\author{
KIRAN K. SHARMA* and RODOMIRO ORTIZ
}

\begin{abstract}
Genetic Resources and Enhancement Program, International Crops Research Institute for the Semi-Arid Tropics (ICRISAT), Patancheru, Andhra Pradesh 502 324, India
\end{abstract}

(Received 3 September 1999; accepted 6 November 1999; editor T. A. Thorpe)

\begin{abstract}
Summar y
The semi-arid tropics are characterized by unpredictable weather, limited and erratic rainfall and nutrient-poor soils and suffer from a host of agricultural constraints. Several diseases, insect pests and drought affect crop productivity. Developing stress-resistant crops has been a worthwhile activity of the International Crops Research Institute for the SemiA rid Tropics (ICRISAT). Mandated crops of ICRISAT, including groundnut, pigeonpea, chickpea, sorghum and pearl millet, are the main staple foods for nearly one billion people in the semi-arid tropics. Genetic transformation provides a complementary means for the genetic betterment of the genome of these crops. Judicious application of biotechnological tools holds great potential for alleviating some of the major constraints to productivity of these crops in the agricultural systems of the semi-arid tropics. This article reviews plant genetic engineering in relation to its applications in genetic enhancement and the improvement of important crops of the semi-arid tropics. For the benefit of nonbiotechnologists, a brief review of technical aspects of plant genetic engineering is also included.
\end{abstract}

Key words: chickpea; groundnut; millet; pigeonpea; sorghum; transgenics.

\section{Introduction}

Conventional plant breeding, combined with improved agricultural practices and modern technology, has contributed to dramatic crop improvements over the past $50 \mathrm{yr}$ and will continue to provide future benefits. However, there is intense pressure to produce further improvements in crop quality and quantity as a result of population growth, social demands, health requirements, environmental stresses and ecological considerations. The world's population is predicted to reach eight billion by the year 2010 . To feed three billion additional people in the next $20 \mathrm{yr}$ will require a dramatic increase in crop production, a formidable task by any standard. Conventional plant breeders and related scientists have worked diligently and skilfully to upgrade quality and raise yields by employing various crop improvement techniques and have obtained commendable results. For example, the combined production of 17 major crops in the United States increased by over $242 \%$ between 1940 and 1980, while acreage under cultivation increased by $\sim 3 \%$ (Borlaug, 1983).

Notwithstanding these impressive gains in productivity, there are limitations to conventional plant breeding technology either due to the limited gene pool or to the restricted range of organisms between which genes can be transferred due to species barriers. $\mathrm{N}$ ew biotechniques, in addition to conventional plant breeding, are needed to boost yields of the crops that feed the world (Borlaug,

\footnotetext{
${ }^{*}$ A uthor to whom correspondence should be addressed; Email k.sharma@ cgiar.org
}

1997; Ortiz, 1998). The newly acquired ability to transfer genes between organisms without sexual crossing provides breeders with new opportunities to improve the efficiency of production and to increase the utility of agricultural crops. Plants with new traits, such as resistance to herbicides, insect pests and viruses, have been genetically engineered using genes from unrelated organisms. However, it should be emphasized that biotechnology is not a substitute for conventional breeding methods but a means of improving on them. The major differences between conventional breeding and biotechnology lie neither in goals nor processes, but rather in speed, precision, reliability and scope.

Plant biotechnology offers new ideas and techniques applicable to agriculture. It uses the conceptual framework and technical approaches of plant tissue culture and molecular biology to develop commercial processes and products. Hence, with the rapid development of biotechnology, agriculture has moved from a resource-based to a science-based industry. The technology required for engineering transgenic plants is considerably more sophisticated than that for producing somatic hybrid plants and much more so than that required for production of hybrid plants by cross-fertilization (Goodman et al., 1987; K ung, 1993; Birch, 1997).

Nonsexual DNA transfer techniques make possible manipulations that are outside the repertoire of breeding or cell fusion techniques. Genes can be accessed from exotic sources- plant, animal, bacterial, even viral - and introduced into a crop. Because the DNA elements that control gene expression can, and often must, be modified for proper function in the new host it is possible to control timing, tissue specificity and expression level of transferred genes. Endogenous plant genes may even be reprogrammed through 
the reintroduction of an engineered gene (Maniatis et al., 1987; Schibler and Sierra, 1987).

The semi-arid tropics. These environments are home to onesixth of the world's population and are where the world's hungriest people live. With the expanding population, the big challenge is to meet the food needs of the semi-arid tropics or the 'home of the hungry'. Chickpea, groundnut, millet, pigeonpea and sorghum [International Crops Research Institute for the Semi-Arid Tropics (ICRISAT) mandate crops] and cassava are among the most important crops of the semi-arid tropics. A chieving sustainable food production in these fragile lands requires new tools for genetic enhancement, especially when agrochemicals are frequently inaccessible to farmers. Long dry seasons, unpredictable rainfall and poor soils, along with susceptibility to many insect pests and diseases, affect crop productivity in the semi-arid tropics. A griculture in these environments means growing marginal crops on marginal lands with marginal resources.

\section{Genet ic Engineering of $\mathrm{Pl}$ ant $\mathrm{S}$}

With the advent of recombinant DNA methods and transformation procedures, it is possible to transfer genes into crop plants from unrelated plants, microbes and animals. Many of the modifications being carried out, or envisaged, are for disease, pest or herbicide resistance. Because of these possibilities, it is now feasible to introduce into crop plants genes that have previously been inaccessible to the conventional plant breeder or which did not exist in the crop of interest. However, the lack of availability of efficient transformation methods to introduce foreign DNA can be a substantial barrier to the application of recombinant DNA methods in some crop plants. Despite significant advances over the past decade, the development of efficient transformation methods can take many years of painstaking research. The major components for the development of transgenic plants are: (1) the development of reliable tissue culture regeneration systems; (2) preparation of gene constructs and transformation with suitable vectors; (3) efficient techniques of transformation for the introduction of genes into the crop plants; (4) recovery and multiplication of transgenic plants; (5) molecular and genetic characterization of transgenic plants for stable and efficient gene expression; (6) transfer of genes to elite cultivars by conventional breeding methods if required; and (7) evaluation of transgenic plants for their effectiveness in alleviating biotic and abiotic stresses without causing environmental problems (Birch, 1997). Some of the key characteristics of these components are as follows.

Reliable systems for whole plant regeneration in tissue cultures. Transformation of plants involves the stable introduction of DNA sequences usually into the nuclear genome of cells capable of giving rise to a whole transformed plant. Transformation without regeneration, and regeneration without transformation, are of limited value. The very basis of regeneration in tissue cultures is the recognition that somatic plant cells are totipotent (i.e. capable of giving rise to whole plant) and can be stimulated to regenerate into whole plants in vitro, via organogenesis (shoot formation) or somatic embryogenesis, provided they are given the correct hormonal and nutritional conditions (Skoog and Miller, 1957). A dventitious shoots or embryos are thought to arise from single cells. Thus, providing totipotent cells that can be identified as being both competent and accessible for gene transfer, and will give rise directly to nonchimeric transformed plants, is essential for genetic transformation. Transformation techniques reliant on plant regeneration from in vitro-cultured tissues have been described for many species (Draper et al., 1988; Lindsey and Jones, 1989; Dale et al., 1993; Birch, 1997).

Selectable markers. The genetic transformation of plants requires 'marker' genes that allow the recognition of the transformed cells. These genes are dominant, usually of microbial origin, and placed under the control of strong, constitutive, eukaryotic promoters, often of viral origin (Birch, 1997). The most popular selectable marker genes used in plant transformation vectors include constructs providing resistance to antibiotics such as kanamycin and hygromycin and genes that allow growth in the presence of herbicides such as phosphinotricin, glyphosate, bialaphos and several other chemicals (Wilmink and Dons, 1993). For successful selection, the target plant cells must be susceptible to relatively low concentrations of the antibiotic or herbicide. Screenable marker 'reporter genes' have also been developed from bacterial genes coding for easily assayed enzymes, such as chloramphenicol acetyl transferase (CAT), $\beta$-glucuronidase (GUS), luciferase (LUX), green fluorescent protein (GFP; Reichel et al., 1996), nopaline synthase and octopine synthase (HerreraEstrella et al., 1988). The utility of any particular gene construct as a transformation marker varies depending on the plant species and explant involved. To date kanamycin resistance (R eiss et al., 1984) is the most widely used selectable marker phenotype and GUS (J efferson et al., 1987) is the most widely used screenable marker.

Suitable vectors. Most commonly used plant transformation vectors have features required for various recombinant DNA manipulations that include multiple unique restriction sites, bacterial origins of replication and prokaryotic selectable markers for plasmid selection and maintenance in Escherichia coli (e.g. antibiotic resistance). In addition all these vectors contain specific selectable marker genes engineered for expression in plants and may be used directly as transformation vectors in physical DNA delivery strategies such as particle bombardment. However, for use in Agrobacterium-mediated gene transfer these vectors need additional features such as wide host range replication and transfer functions to allow conjugation from E. coli to Agrobacterium and plasmid maintenance in both bacterial hosts (K lee et al., 1987).

Efficient techniques for transformation. The unavailability of efficient transformation methods to introduce foreign DNA can be a substantial barrier to the application of recombinant DNA methods in some crop plants. However, there have been significant advances over the past decade. The development of efficient transformation methods is frequently not straightforward and can take many years of painstaking research with a range of different methods (Potrykus, 1990, 1991). Although several approaches have been tried successfully for integrative transformation (Potrykus, 1991) only three are widely used to introduce genes into a wide range of crop plants (Dale et al., 1993). These include (i) Agrobacterium-mediated gene transfer, (ii) microprojectile bombardment with DNA or biolistics and (iii) direct DNA transfer into isolated protoplasts. Of these techniques the first two approaches have been more successful.

i. A grobacterium-mediated gene transfer. Agrobacterium tumefaciens is a soil bacterium that causes gall formation at the wound sites of many dicotyledonous plants. This tumor-inducing capability is due to the presence of a large Ti (tumor-inducing) plasmid in 
virulent strains of Agrobacterium. Likewise, Ri (root-inducing) megaplasmids are found in virulent strains of Agrobacterium rhizogenes, the causative agent of 'hairy root' disease. $\mathrm{Ti}$ and $\mathrm{Ri}$ plasmids and the molecular biology of crown gall and hairy root induction have been studied in great detail (Klee et al., 1987; Lichtenstein and Fuller, 1987; Binns and Thomashow, 1988; Zambryski, 1988, 1992; Zambryski et al., 1989). The number of plant species transformed by Agrobacterium vectors has increased steadily over the past few years, and representatives of many taxonomically diverse genera have proved amenable to transformation (Dale et al., 1993). This success can mainly be ascribed to improvements in tissue culture technology, particularly adventitious shoot regeneration in the crop plants concerned. Notable by their absence from this list are the majority of the major seed legumes and monocotyledonous plants. 'A groinfection' studies (Grimsley et al., 1987, 1988) indicate that although the T-DNA transfer to monocot cells occurs, the block to transformation by Agrobacterium may lie in the wound response of monocotyledonous cells and possibly a lack of competence for T-DNA transport to the nucleus or its integration. The important requirements for transformation by Agrobacterium are that first, the plant explants must produce some active compounds like acetosyringone in order to induce the vir genes present on the Ti plasmid, and then the induced agrobacteria must have access to competent plant cells that are capable of regenerating adventitious shoots or somatic embryos at a reasonable frequency. There is evidence to suggest that for gene transfer to occur cells must be replicating DNA or undergoing mitosis (Meyer et al., 1985; Okada et al., 1986; Binns and Thomashow, 1988; Moloney et al., 1989; Sharma et al., 1990). The majority of transformation experiments utilize either freshly explanted tissue sections, protoplasts in the process of reforming a cell wall and entering cell division or callus and suspension-cultured cell clumps wounded by chopping or pipetting and stimulated into rapid cell division by the use of nurse cultures (Draper et al., 1988). Adventitious shoot production in vitro is most commonly employed in most systems. The major problem in the development of a transformation system is providing induced Agrobacterium with access to cells capable of dedifferentiation followed by regeneration. Thus, it is often difficult to combine transformation competence with totipotency (Birch, 1997) even though in some species, such as tobacco and Brassica napus, this combination can be achieved with relative ease (Horsch et al., 1984; Moloney et al., 1989).

ii. Microprojectile bombardment with DNA or biolistics. Acceleration of heavy microprojectiles (0.5-5.0 $\mu \mathrm{m}$ diameter tungsten or gold particles) coated with DNA has been developed into a technique that carries genes into virtually every type of cell and tissue (Klein et al., 1988; Sanford, 1990). This method allows the transport of genes into many cells at nearly any desired position in a plant. The technology basically involves loading tiny tungsten or gold particles with vector DNA and then spreading the particles on the surface of a mobile plate. Then, under a partial vacuum, the 'microprojectile' is fired against a retaining plate or mesh, by a shock wave caused by helium under pressure achieving speeds of one to several hundred meters per second. The macroprojectile decelerates instantly, whilst the momentum and small size of the dense microprojectiles causes them to be thrown from the surface of the macroprojectile and to penetrate the target plant tissue. The particles are capable of penetrating several layers of cells, and allow the transformation of cells within tissue explants. By eliminating the need for passage through a protoplast stage, the particle gun method has the potential to allow direct transformation of commercial genotypes. This technique, although not as efficient as the Agrobacterium-mediated gene transfer, has a distinct advantage in that virtually any type of meristematic totipotent cells, tissues, organs and monocots that are not readily amenable to agroinfection can be used with a reasonable success rate. A nother major advantage of the biolistic technique lies in its application in transient gene expression studies in differentiated tissues (Klein et al., 1992).

iii. Direct DNA transfer into isolated protoplasts. Direct gene transfer by using isolated protoplasts (Roest and Gilissen, 1989) is an alternative to the use of Agrobacterium which is useful because of the foreseeable difficulties with cereal crops. Virtually every protoplast system has proven transformable, though with differing efficiencies. Unfortunately, there are severe problems with the recovery of transgenic plants from protoplasts. Plant regeneration from protoplasts is a delicate process and depends upon parameters that are not under experimental control [e.g. species- and genotypedependent competence for wound response and regeneration (Potrykus and Shillito, 1989)]. DNA transfer into protoplasts can be successfully promoted by various treatments, including polyethylene glycol, electroporation and microinjection (Potrykus, 1991). Of these methods the first two approaches seem more promising.

Recovery and characterization of transformed plants. Once the target cells have been transformed by one of the above methods the transgenic cells or plants thus produced are selected on a selection medium. Almost all the transformation methods require the incorporation of a selectable marker gene into the gene vector construct used to introduce the genes of interest. The selectable marker most commonly used is NPT II (neomycin phosphotransferase), which confers resistance to kanamycin. A marker gene is necessary because only a small proportion of the cells exposed to the transformation process subsequently become stably transformed (Klee et al., 1987). Selecting on the selective medium gives an advantage to those cells that have stably incorporated the transgene construct and are therefore resistant to the selective antibiotic. The putative transgenic plant after selection is propagated in vitro, followed by rooting and transfer to the containment glasshouse for further evaluation and production of seeds for subsequent sexual generation.

Periodically, the transgenic plants need to be confirmed for the presence and expression of the introduced gene by molecular methods followed by genetic characterization (see Birch, 1997). The number of copies of a transgene construct inserted is variable for all transformation methods. The integration of a single T-DNA copy is common, but high numbers are also observed. Data from several different transgenic dicotyledonous species showed an average of three T-DNA inserts, with occasionally up to 20 - 50 copies in some plants. In a segregation analysis of 161 transgenic plants, 55\% segregated for one copy, $20 \%$ for two unlinked copies, $6 \%$ for three unlinked copies and $1 \%$ for four unlinked copies. The remainder did not segregate in a simple Mendelian ratio (Zambryski, 1988). The position of the T-DNA insertion also appears to be random within the nuclear genome. The expression of transgenes can vary considerably between different independently transformed plants (H obbs et al., 1990; J efferson et al., 1990; Blundy et al., 1991). In 
some instances there is a positive association between transgene expression and copy number, but other studies have shown no association or even a negative one ( $\mathrm{H}$ obbs et al., 1990). Transgene expression may sometimes be unstable or may decline over generations (V aucheret et al., 1998).

There could be several reasons for nonexpression or low expression of the transgene in a transgenic plant (Finnegan and McElroy, 1994; Matzke and Matzke, 1995; Meyer, 1995; Stam et al., 1997). These include pleiotropic effects from transgenes, somaclonal variations in the regenerated transgenic plants or environmental effects on the promoters driving the transgenes. The practical way of avoiding problems associated with variation in transgene expression and stability, and somaclonal variation (if any), is to produce a large number of independently transformed plants (often >100) and to select those with a desirable phenotype (see Birch, 1997). Except for vegetatively propagated crop plants, it is usually desirable to identify genotypes with single inserts of the transgene construct which will have simpler inheritance patterns and are likely to have more predictable transgene expression levels in subsequent segregating populations.

The transgenic status of the transgenic plants is confirmed by assaying for expression of the transgenes inserted. Stable integration and the number of copies of the inserted DNA are confirmed by Southern hybridization while the gene expression (mRNA) is confirmed by Northern hybridization and protein synthesis by Western blotting (Sambrook et al., 1989). The introduced transgene should follow a Mendelian inheritance pattern for its stable expression and inheritance. Following initial analysis, the transgenic plants need to be moved into a containment glasshouse for further phenotypic and genotypic analysis using the original nontransgenic genotype as a control. Further evaluation of the transgenic plants is done under agronomic conditions by carrying out field assessment studies. Risk assessment to study the effect of the transgene on the environment, livestock and human health needs to be carried out before each novel type of transgenic plant is grown in small-scale field trials, and before they are used in transgenic crop cultivars under a nonregulated status. The field evaluation and risk assessment have to be performed according to the biosafety guidelines of the host country, under the immediate guidance and supervision of the Institute Biosafety Committee (IBSC). Assessment procedures are being harmonized internationally by various organizations (Levin and Strauss, 1993).

\section{Opportunities for Improving Crops of the Semi-Arid Tropics}

There are several biotic constraints to the productivity of most important crops in the semi-arid tropics. It is possible to develop resistant or tolerant cultivars for some of these constraints by using the resistance genes already available in the cultivated or wild germplasm by conventional plant breeding. However, in other cases either the resistance genes do not exist in the current germplasm or it is not possible to transfer the resistance genes from wild species due to interspecific barriers. Where possible some of these wild species are being used for transferring genes to cultivated genotypes or species by interspecific hybridization involving modern methods of tissue culture and embryo rescue. Some of the major constraints to the high productivity of crops in the semi-arid tropics that are currently being addressed or can be addressed in the future by plant genetic engineering are explained below for each individual crop.
Sorghum. This crop [Sorghum bicolor (L.) Moench.] ranks fifth among cereals and is grown in the tropical and subtropical regions of the world ( 86 countries) between $40^{\circ}$ north and $40^{\circ}$ south of the equator. Sorghum is a major staple in the diets of the people of the semi-arid tropics. The crop was probably domesticated between W estern Ethiopia and Chad. The major stresses affecting sorghum production are drought, low temperature, the parasitic weed Striga, grain mold fungal diseases, anthracnose, foliar fungal diseases and insect pests such as stem borer, shoot fly, midge and head bugs. The main goal of sorghum breeding in the semi-arid tropics is improved and stable grain yield ensuing from enhanced crop adaptation to both biotic and abiotic stresses (Miller et al., 1997). Some of the major constraints that can be addressed by its genetic transformation are as follows.

Striga. This is a major field disease on sorghum in the tropics and especially in A frica. A nnual losses to sorghum production due to this disease are over US\$500 million, of which US $\$ 153$ million is attributable to Africa alone. Resistance sources have been identified but the incorporation of resistance by traditional breeding practices is difficult and time-consuming (Ejeta et al., 1997). Hence the identification of novel genes for resistance to Striga could provide great benefits.

Root and stalk rots. This disease is found under terminal drought conditions, where it can be caused by weakly parasitic fungi such as F usarium and Macrophomina. Under such conditions these fungi result in severe lodging and loss of valuable stover for cattle. There is little or no genetic resistance available in the germplasm (Thakur et al., 1997). A genetic linkage map was derived from a cross between B 35 (nonsenescent or staygreen) and Tx7078 (high yield potential but highly senescent and drought- and disease-susceptible, resulting in severe premature lodging). A t least six DNA markers appear to be associated with the above traits. Genetically engineered sorghum will further dramatically increase the grain yield by preventing premature termination of growth, and will increase the quality and quantity of stover.

Grain mold. A variety of fungi attacks developing grains and reduces grain quality (which include mycotoxin production), resulting in worldwide annual yield losses of up to US\$130 million. Conventional methods of breeding have produced some degree of protection, but this is inadequate (Stenhouse et al., 1997). Use of fungicides is not a viable option as the disease occurs during wet weather when spraying is not effective. Small-scale farmers growing sorghum are the worst affected because they cannot afford to artificially dry the grains immediately after harvest in order to mitigate losses due to grain mold. Existing resistance sources can confer only limited protection by way of phenolic compounds in brown grain sorghums, which may decrease nutritional quality. The resulting grain is not acceptable to most consumers and farmers suffer in the marketplace. The best alternative would be to produce transgenic sorghum with genes coding for antifungal proteins in the ovary and the developing grain (Stenhouse et al., 1997). Access to these genes with appropriate promoters will enable the production of transgenic plants in a variety of genetic backgrounds.

Insect pests. Stem borers and shoot fly (shoot pests) and head bug and midge (panicle pests) are the most important biotic constraints to sorghum production (Peterson et al., 1997). They cause combined annual losses estimated at over US\$600 million worldwide. Both shoot fly and stem borers, which include a number of species, occur in A sia and A frica. So far limited success has been 
achieved in improving resistance levels with known sources of resistance within cultivated sorghum. While considerable progress in breeding for midge resistance has been made (Henzell et al., 1997), there is a need to develop materials with new resistance genes as the existing resistances seem to break down under conditions of severe infestation. Bacillus thuringiensis $(\mathrm{Bt})$ and other genes with insecticidal activities are being evaluated for eventual use in transforming sorghum and reducing losses due to these pests.

Pearl millet. This cereal crop [Pennisetum glaucum (L.) T.Br.] is the most widely cultivated millet in both arid and semi-arid regions. Pearl millet is grown in environments where conditions are too severe for other crops to grow. The world's hardiest crop is grown mostly in India, Pakistan and $Y$ emen in Asia, and in 29 countries in Africa (Yadav and Weltzien, 1999). More recently, cultivation of this crop in Brazil has been expanded. The crop is grown primarily for grain which is used mainly for human consumption, especially in Africa, but also as cattle and poultry feed in the more favorable environments of A sia. Pearl millet could have been domesticated in a geographic belt stretching from Sudan to Senegal. The most important production constraints are drought, high soil temperature, downy mildew, panicle diseases, striga and insect pests ( $R$ ai et al., 1997). The improvement of grain yield potential through genetic enhancement remains high. One of the approaches to achieve this goal would be to develop germplasm resistant to the stresses affecting grain yield in pearl millet. Some of the main constraints that can be alleviated by genetic transformation are as follows.

Downy mildew. Downy mildew is the most significant biotic constraint to pearl millet production in the semi-arid tropics of A sia and A frica because it can reduce yields by $20-30 \%$ (Singh et al., 1993). The disease is more damaging in genetically uniform singlecross hybrids than on landraces and open-pollinated varieties. Research at ICRISAT during the past two decades has aimed to (i) develop effective field and greenhouse resistance screening techniques, (ii) identify sources of resistance, (iii) determine stability of resistance, (iv) use resistance in breeding hybrids and open-pollinated varieties and (v) control by seed treatment with a systemic fungicide (metalaxyl). However, the fungicide control method is costly and as fungicide is not easily available it has not been widely adopted in the semi-arid tropics. Host plant resistance remains the most economical and effective means of managing downy mildew. Transformation of pearl millet by employing antifungal genes would help in the management of this disease.

Pigeonpea, chickpea and groundnut. Chickpea (Cicer arietinum L.) and pigeonpea [Cajanus cajan (L.) Millsp.] are pulse crops of the semi-arid tropics. Chickpea is among the most important pulse crops in South A sia. This crop, which originated in the Middle East, is also widely cultivated in West Asia and North A frica and has become important in Australia, Mexico, southern USA and East Africa (Jodha and Subba Rao, 1987). Chickpea is a traditional source of protein in the Middle East. Pigeonpea has been a staple food of South Asia for millennia but today it is also grown in the Caribbean region and in Eastern A frica, a secondary center of this species (Singh et al., 1990). This legume is an important component of vegetarian diets and sustainable cropping systems. F usarium wilt, sterility mosaic virus and Phytophthora blight (Reddy and Sheila, 1994) are the most important diseases of pigeonpea (Nene, 1988; Reddy et al., 1990) whereas, in chickpea, Ascochyta blight (AB), wilt, root rots, Botrytis gray mold (BGM) and stunt disease caused by a viral complex are among the most important constraints (Nene and Reddy, 1987; Nene, 1988). Insects pests (e.g. Helicoverpa armigera or podborer) and nematodes are other pests affecting these crops (Grec0, 1987; Reed et al., 1987). Genetic enhancement for both stability and productivity are major goals of pulse improvement.

Groundnut (Arachis hypogaea L.) or peanut is grown widely across a broad range of climates and environments. This crop provides both protein and oil and its haulm can be used as livestock feed. A mong the cash crops of the semi-arid tropics, groundnut has a significant export potential. The cultivated groundnut originated in South America, which is the primary center of diversity. There are many biotic and abiotic factors influencing groundnut yield. Drought, high temperature, low soil fertility, low soil pH and iron chlorosis are the most important abiotic stresses. Fungi, nematodes, viruses, bacteria and insect pests are among the major biotic constraints in groundnut production. A flatoxin production caused by Aspergillus flavus affects post-harvest quality. The main goal in groundnut improvement is to develop genotypes with high yield and quality, short cropping duration for specific environments, performance stability and resistance to both biotic and abiotic stresses. Genetic transformation approaches hold great potential for the improvement of these crops as follows.

Insect pests. The productivity of pigeonpea (Singh et al., 1990) and chickpea (Reed et al., 1987) crops is drastically affected by the insect pest Helicoverpa armigera, which causes substantial damage and yield losses every year. In pigeonpea alone, it is estimated that this insect pest causes yield losses equivalent to US\$317 million annually (Shanower et al., 1999). Intensification of agriculture has exacerbated this pest problem, and farmers are responding by using pesticides more frequently and using more toxic pesticides. For pest problems as complex and intractable as Helicoverpa the assumption is that no single control tactic will be successful. It has long been recognized that host plant resistance would be one of the most effective management options for this pest but, thus far, the levels of resistance that have been found in the available germplasm are moderate to low. The genetic engineering of these crops could provide an effective complementary approach to Helicoverpa control. Several insect resistance genes have been identified as candidates for transforming pigeonpea and chickpea, including the genes coding for the insecticidal crystal protein of $\mathrm{Bt}$, soybean trypsin inhibitor (SBTI) and pigeonpea trypsin inhibitor (PPTI).

The groundnut crop is affected by several insect pests, of which the lepidopteran pests such as leaf miner and Spodoptera are the most damaging (Wightman and Ranga Rao, 1993). These cause estimated crop losses of $\sim$ US $\$ 300$ million worldwide. While there is a low level of resistance available for Spodoptera, there is none available for leaf miner. The management practices for these insect pests are potentially rewarding but given the diversity of the farming practices and regions where this crop is grown these options are often not practical or are economically nonviable. The genetic resistance induced by engineering novel insecticidal genes, together with simple and appropriate management practices, would be very useful in alleviating the insect problem in this crop. Insect resistance genes that have been identified as candidates for inducing resistance to these insect pests include the genes coding for the insecticidal crystal protein for Bt and SBTI, either alone or in combination.

F ungal pathogens in chickpea. The chickpea crop is affected by several fungal pathogens as indicated above. ICRISAT, in 
collaboration with the Scottish Crop Research Institute (SCRI) in Dundee, UK, is attempting to incorporate antifungal genes that include polygalacturonase-inhibiting protein ( $P G I P$ ) genes from raspberry (V ohnston et al., 1994) to control both $A B$ and BGM. Once the putative transgenic plants are obtained from SCRI they will be evaluated in the glasshouse and under field conditions. Other attempts aim to introduce genes such as lectins and chitinases that have been shown to possess antifungal properties.

Aflatoxin problem in groundnut. A flatoxins produced in groundnut seeds as a result of post-harvest deterioration due to infection by fungal pathogens like Aspergillus flavus are a major problem with this crop and result in huge annual losses worldwide. The effect of this fungal pathogen occurs in three stages, namely infection, colonization and aflatoxin production (MCDonald, 1989). Various strategies are available that can prevent the damage either by interfering with the first two stages by using antifungal genes like chitinases and beta-glucanases, or by directly interfering with the biosynthetic pathway of aflatoxin production by the fungus. Incorporation of these novel genes has been shown to control damage due to this pathogen in some crops.

Virus diseases of groundnut. At least five viruses affect the productivity of groundnut production. These viruses are Indian peanut clump virus (IPCV), groundnut rosette virus (GRV), peanut bud necrosis virus (PBNV), peanut stripe virus (PStV) and peanut mottle virus (PMV) (Reddy, 1991). Currently ICRISAT is focusing mainly on IPCV and GRV because of their economic importance in A sia and A frica respectively and the lack of any durable host plant resistance. Coat protein gene of IPCV (Wesley et al., 1994) has been cloned and some transgenic groundnut plants have been generated (Sharma, K. K., unpublished results). After conducting further tests on the expression of viral genes in transgenic plants they will be utilized in laboratory tests for evaluating resistance to IPCV. Besides the coat protein gene of IPCV, replicase gene has also been cloned and is being used to produce transgenic plants (Miller et al., 1996).

ICRISAT also intends to incorporate coat protein gene of groundnut rosette assistor virus (GRAV; a component of the GRV complex) to enhance the host plant resistance to GRV that has been incorporated earlier by conventional breeding procedures (Subrahmanyam et al., 1998). The coat protein genes, replicase and satellite sequences of these viruses are available (Blok et al., 1994; Scott et al., 1996; Taliansky et al., 1998).

Nematode pests in crops of the semi-arid tropics. Meloidogyne spp. are internationally important nematode pests of groundnut, chickpea and pigeonpea, while Pratylenchus spp. are important pests of these crops as well as of sorghum and pearl millet (Sharma and McDonald, 1990). In addition, Heterodera cajani and Rotylenchus reniformis are important pathogens of pigeonpea in India. Nematodes are one of the most important constraints to crop productivity and, on a worldwide basis, they cause heavy annual losses in the yields of important food and fiber crops (Sasser and Freckman, 1987; Barker et al., 1994). Chemical control of nematodes, though very effective, has proved too expensive for the developing countries ( $\mathrm{H}$ ague and Gowen, 1987). The economic losses caused by plant parasitic nematodes worldwide are estimated to be in the vicinity of US\$328 million (13.7\%) for chickpea, US\$177 million (13\%) for pigeonpea and US\$1 billion (12\%) for groundnut (Sasser and Freckman, 1987). Screening of over 6000 chickpea genotypes for resistance to Meloidogyne spp. at ICRISAT revealed that resistance in the primary as well as secondary gene pools of chickpea is not readily available (see, e.g., Sharma et al., 1993b). An evaluation of 58 pigeonpea cultivars and 61 accessions of pigeonpea and its wild relatives found eight accessions of wild relatives that were resistant (Sharma et al., 1993a). This provides unique opportunities to transfer genes into the cultivated pigeonpea and even clone the genes for resistance. Parasitic nematodes have also been found to reduce the resistance levels to pathogenic fungi even in otherwise resistant cultivars (Sharma, 1985). Hence, engineering resistance against nematodes will increase the productivity and yield of these crops. As the nematodes generally lower the resistance of their hosts against other pathogens and stressors, it is expected that the engineered resistance might introduce a measure of tolerance to them, thereby increasing the general health of the crop and decreasing the need for fungicides and pesticides.

\section{Transgenic Research for the Semi-Arid Tropics of Africa}

Diseases and insect pests can destroy entire crops and cause catastrophic economic losses in the farming systems of the semiarid tropics. Therefore, the most important applications of biotechnology for plant protection among ICRISAT mandate crops, especially in Africa, include striga, root and stalk rots, grain mold and insect pests in sorghum, downy mildew in pearl millet, rosette virus and peanut clump virus in groundnut, pod borer in chickpea and pigeonpea and root-knot nematodes in chickpea, pigeonpea and groundnut.

Resistant germplasm offers a means to overcome these agricultural constraints affecting crop productivity in environments typified by a host of biotic stresses. Of course the war on pests and pathogens is being waged on many fronts besides host plant resistance, e.g. biological control or improved crop husbandry. However, genetic enhancement offers an easy, cheap and sustainable technology for transfer to farmers of the semi-arid tropics.

\section{Current Stat us of Genetic Transformation of Crops of the Semi-Arid Tropics}

Efficient tissue culture and transformation methods based on biolistic- and Agrobacterium tumefaciens-mediated gene transfer are available in groundnut (Sharma, K.K. et al., 1993a,b). Using these methods, transgenic plants containing the coat protein gene of peanut clump virus (PCV) have been produced and are currently being characterized in the glasshouse by ICRISAT scientists. Specific field trials are planned, and production of transgenic plants with coat protein genes and polymerase genes of some other viruses is ongoing.

Efficient tissue culture methods have been developed for pigeonpea (Chintapalli et al., 1997). They have been used in producing transgenic plants with Bt Cry I(A) and SBTI genes for inducing insect resistance. These plants are currently being characterized at the laboratory level by ICRISAT staff at Patancheru.

Tissue culture systems based on shoot regeneration from embryo axis explants and somatic embryogenesis from embryo axis and leaflet explants have been developed for chickpea. Transformation studies are underway. A transformation system for chickpea has been developed by SCRI but its efficiency and reproducibility 
remains to be verified (Senthil et al., 1998). In this study some transgenic plants of chickpea have been produced that carry PGIP for inducing resistance to $B G M$.

Tissue culture research is underway to develop transformation methods for both sorghum and pearl millet. However, protocols are not yet available for the routine development of transgenic cultivars of both species.

\section{Comparative Advantage of Transformation Research at ICRISAT}

The major advantages of doing genetic transformation work at ICRISAT are the availability of excellent laboratory, glasshouse and field facilities. The availability of interdisciplinary teams comprising cell biologists, plant breeders and crop protection scientists provides a unique opportunity to develop and implement strategies for crop improvement using the tools of biotechnology. Over the past 5- $6 \mathrm{yr}$, tremendous progress has been made at ICRISAT in the development of tissue culture and transformation protocols for the most important crops of the semi-arid tropics. An outline of the comparative advantages of ICRISAT follows.

1. A vailability of dedicated laboratory and glasshouse facilities.

2. A vailability of in-house expertise on tissue culture, transformation and molecular biology for chosen crops of the semi-arid tropics.

3. A vailability of tissue culture and transformation methods for introducing foreign genes into groundnut and pigeonpea.

4. Transformation methodology for transforming chickpea has recently become available through our collaborative projects with SCRI and V rije Universitiet Brussels (VUB, Belgium).

5. Some of the important genes for inducing resistance to groundnut viruses, insect pests and fungal pathogens are available within ICRISAT. More genes will be available as a result of our ongoing collaborations with advanced research institutions (ARIS).

6. A major advantage of carrying out work on the evaluation of transgenic plants at ICRISAT is the availability of crop protection scientists and of experimental sites in hot spots for various biotic stresses within ICRISAT and India, or through our presence in Africa.

7. For carrying out work on various aspects of transformation, local scientific expertise as well as potential self-funded research scholars are readily available from local universities and institutions. Indian scientists have shown a very keen interest in adopting these technologies as part of proposed collaborative projects in the future.

8. Secure field facilities of ICRISAT in its experimental fields at Patancheru can be readily utilized for field evaluations after obtaining formal permission from the Government of India through the Biosafety Committee.

\section{Bottl enecks in the Transformation of Crops of the Semi-Arid Tropics}

A current limitation to the practical transformation of many plant species of the semi-arid tropics is the low frequency of tissue culture regeneration, leading to very low success rates of genetic transformation. However, the methods for gene transfer into plant cells, particularly Agrobacterium-mediated and particle bombard- ment, are now sufficiently developed to allow transformation of essentially any plant species in which regenerable cells can be identified (Birch, 1997).

A major bottleneck in the future applications of genetic transformation, especially in the context of agriculture in the semi-arid tropics, will be in the availability of novel genes and effective promoters for high and tissue-specific expression of the introduced genes due to intellectual property issues. Commercial limitations might eventually become more serious barriers to the exploitation of genetic transformation technology for the resourcepoor farmers of the semi-arid tropics. Currently most of the established or promising plant genetic transformation strategies are covered by patents owned by private biotechnology companies (see, e.g., Sanford et al., 1990, 1992; Schilperoort et al., 1990; $\mathrm{H}$ iei and Komari, 1994; Coffee and Dunwell, 1995; Maliga and Maliga, 1995; Paszkowski et al., 1995) which cover many isolated genes, promoters and techniques for plant gene manipulation, thereby leading to various implications (Birch, 1997). These aspects can most effectively be handled either by worldwide initiatives on intellectual property right (IPR) issues or through the development of expertise in gene identification and cloning in the developing world. The latter approach seems most promising because it can utilize the vast genetic resources for gene cloning available in gene banks and in situ, and with collaboration from ARIs.

Due to the current lack of proper biosafety regulations in many developing countries in the semi-arid tropics it may not be very easy to either carry out field testing of genetically modified crops or to release germplasm-containing transgenes. One of the endeavors of an institute like ICRISAT may be to study and enhance public and government perceptions on genetically modified organisms and their applications to sustainable agriculture in semi-arid tropical countries. Likewise, ICRISAT staff may facilitate or cooperate with national governments in the development of biosafety guidelines, which must meet international standards for deploying transgenic crops.

\section{Partnerships for Collaborative Research on $\mathrm{G}$ enetic $\mathrm{Tr}$ ansformation}

Basic research. ICRISAT has already developed need-based strategic links with ARIs and National Agricultural Research Systems (NARS) partners for the facilitation of the effective development of transformation and gene cloning activities. Some of the genes currently being used at ICRISAT have been made available as part of these links. ICRISAT currently has collaborative projects with the following partners.

1. SCRI at Dundee (UK) for transgenic chickpea with resistance to $B G M$ and virus resistance in groundnut.

2. VUB at Brussels (Belgium) for transgenic chickpea and pigeonpea for nutritional and anti-nutritional factors, and resistance to insect pests.

3. Plant Biotechnology Institute (PBI), National Research Council of Canada at Saskatoon (Canada) for cloning of insecticidal genes and tissue-specific promoters.

4. National Chemical Laboratory (NCL) at Pune (India) for tissue culture of chickpea and pigeonpea.

5. Indian Institute of Pulses Research at Kanpur (India) for insect resistance in pigeonpea. 
6. Osmania University at H yderabad (India) for disease resistance in pigeonpea.

7. University of Hyderabad at Hyderabad (India) for disease resistance in groundnut.

Applied research. Once the products of our efforts on genetic transformation of the most important crops of the semi-arid tropics are available after preliminary in-house glasshouse and field trials, links will be developed with partners in the NARS to carry out extensive field trials after obtaining permission from the regulatory body of the host country. At present the Indian NARS have expressed interest in collaborations on the field testing for local constraints. These links will be formalized in due course as part of the joint activities of ICRISAT and the Indian Council of Agricultural Research (ICAR). For example, the Department of Biotechnology (DBT), which is the regulatory body for India, has expressed its keen interest in field testing of groundnut transgenic plants for resistance to an Indian isolate of PCV.

Glasshouse and field testing of transgenic plants for some of the biotic constraints affecting crop productivity, especially in A frica, can be facilitated by our ARI partners. For example, SCRI is keen on testing the transgenic plants for resistance to GRV because they have the facilities to test for this virus in their glasshouses. Due to their past involvement in epidemiology studies in Malawi, they could facilitate the field studies. Strategic alliances for other constraints will have to be established to seek common funding from donors.

Partnership building for evaluation and utilization of transgenic crops in the semi-arid tropics. A ny crop improvement program that involves the release of improved germplasm in the production systems of the NARS necessitates their active participation in the form of coordinated field trials and evaluations. Similarly, if a crop improvement program includes biotechnological interventions to introduce novel genetic traits the participation of NARS in field testing becomes imperative. The primary role of an international agricultural research center like ICRISAT is to develop the basic germplasm by using biotechnological tools and to test the expression and integrity of the introduced genes. Further testing and evaluation of the new germplasm should be done in partnership with the host country agencies that regulate genetically modified organisms and are responsible for agricultural development. These research and development partnerships will allow the implementation of a better farming system in the semi-arid tropics. Human resources research and development networks are also means to enhance the ability of national scientists in the development and release of transgenic crops.

\section{Out I ook}

Genetic transformation offers a complementary means to conventional crop breeding, especially for characteristics that are rare or may not be available in the investigated genetic resources of a specific crop. Transformation systems have been developed in collaboration with ARIs for pulse crops, and their protocols are being adapted or improved at ICRISAT. The current target of this work is focused on Helicoverpa resistance in pulses, as well as virus and aflatoxin resistance in groundnut.

We consider genetic transformation to be a tool that may allow the breaking of old barriers (as mentioned above) to high productivity of the food crops of the people living in the semiarid tropics. Introducing new genes governing specific characteristics (e.g. better disease and pest resistance) that enhance yield may produce a means to improve crop productivity in the semi-arid tropical world. With the rapid progress in genetic mapping, and the isolation of genes from widely different organisms, there will be new opportunities to modify crop plants using a range of genetic strategies. These gains in crop productivity through scientific advances in genetic enhancement will help to achieve sustainable food security, poverty reduction and environmental protection. There is a growing commitment to transfer the benefits of the new technologies to developing countries, as genes relevant to their crops and environments become available. Hence this research on transgenic crops provides new tools to enable ICRISAT to realize its mission, namely to apply science to improve agriculture in areas of the world where low rainfall and biotic stresses are the major constraints for crop productivity.

\section{Ref er ences}

Barker, K. R.; Hussey, R. S.; K rusberg, L. R., et al. Plant and soil nematodes. Societal impact and focus for the future. J. Nematol. 26:126-137; 1994.

Binns, A. N.; Thomashow, M. F. Cell biology of Agrobacterium infection and transformation of plants. Annu. Rev. Microbiol. 42:575-606; 1988.

Birch, R. G. Plant transformation: problems and strategies for practical application. Annu. Rev. Plant Physiol. Mol. Biol. 48:297- 326; 1997.

Blok, V. C.; Ziegler, A.; Robinson, D. J., et al. Sequences of 10 variants of the satellite-like RNA-3 of groundnut rosette virus. Virology 202:25-32; 1994.

Blundy, K. S.; Blundy, M. A. C.; Carter, D., et al. The expression of class-1 patatin gene fusions in transgenic potato varies with both gene and cultivar. Plant Mol. Biol. 16:153-160; 1991.

Borlaug, N. E. Contributions of conventional plant breeding to food production. Science 219:689-693; 1983.

Borlaug, N. E. Feeding a world of 10 million people: the miracle ahead. Plant Tiss. Cult. Bio/Technol. 3:119-127; 1997.

Chintapalli, P. L.; M oss, J. P.; Sharma, K. K., et al. In vitro culture provides additional variation for pigeonpea [Cajanus cajan (L.) Millsp.] crop improvement. In Vitro Cell. Dev. Biol. - Plant 33:30-37; 1997.

Coffee, R.A., Dunwell, J.M., Transformation of plant cells. US Pat. No. $5,464,765 ; 1995$

Dale, P. J.; Irwin, J. A.; Scheffler, J. A. The experimental and commercial release of transgenic crop plants. Plant Breed 111:1-22; 1993.

Draper, J.; Scott, R.; Armitage, P., et al. Plant genetic transformation and gene expression: a laboratory manual. Oxford: Blackwell; 1988.

Ejeta, G., Butler, L.G., H ess, D.E., et al., Breeding for Striga resistance in sorghum. In: Proc. Int. Conf. Genet. Improvement of sorghum and pearl millet. Lubbock, TX: INTSOR MIL Publ. N 0., 97-5; 1997; 504516.

Finnegan, J.; McElroy, D. Transgene inactivation: plant fight back! Bio/ Technology 12:883-888; 1994.

Goodman, R. M.; Hauptli, H.; Crossway, A., et al. Gene transfer in crop improvement. Science 236:48-54; 1987.

Greco, N. Nematodes and their control in chickpea. Saxena, M. C.; Singh, K. B. The chickpea. Wallingford, UK: CAB International; 1987:271281.

Grimsley, N. H.; Hohn, T.; Davies, J. W., et al. Agrobacterium-mediated delivery of infectious maize streak virus into maize plants. Nature 325:177-179; 1987.

Grimsley, N. H.; Romoss, C.; Hohn, T., et al. Meristematic tissues of maize plants are most susceptible to agroinfection with maize streak virus. Biotechnology 6:185-189; 1988.

Hague, N. M. H.; Gowen, S. R. Chemical control of nematodes. Brown, R. $H$.; Kerry, B. R. Principles and practice of nematode control in crops. Sydney: A cademic Press; 1987:131-178. 
Henzell, R.G., Peterson, G.C., Teetes, G.L., et al. B reeding for resistance to panicle pests of sorghum and pearl millet. In: Proc. Int. Conf. Genet. Improvement of sorghum and pearl millet. Lubbock, TX: INTSORMIL, Publ. No. 97-5 (1997) 225-280.

Herrera-Estrella, L.; Teeri, T. H.; Simpson, J. Use of reporter genes to study gene expression in plant cells. Gelvin, S. B.; Schilperoort, R. A.; Verma, D. P. S. Plant molecular biology manual B1. Dordrecht, The Netherlands: Kluwer; 1988:1-22.

Hiei, Y .; K omari T., Transformation of monocotyledons using Agrobacterium. Int. Pat. W 0 94/00977; 1994.

Hobbs, S. L. A.; K podar, P.; Delong, C. M. O. The effect of T-DNA copy number, position and methylation on reporter gene expression in tobacco transformants. Plant Mol. Biol. 15:851-864; 1990.

Horsch, R. B.; Fraley, R. T.; Rogers, S. G., et al. Inheritance of functional foreign genes in plants. Science 223:496-498; 1984.

J efferson, R.; Goldsbrough, A.; Beven, M. Transcriptional regulation of patatin-1 gene in potato. Plant Mol. Biol. 14:995-1006; 1990.

Jefferson, R. A.; Kavanagh, T. A.; Beven, M. W. GUS fusions: $\beta$ glucuronidase as a sensitive and versatile gene fusion marker in higher plants. EMBO J. 6:3901-3907; 1987.

Jodha, N. S.; Subba Rao, K. V. Chickpea: world importance and distribution. Saxena, M. C.; Singh, K. B. The chickpea. Wallingford, UK: CAB International; 1987:1-10.

J ohnston, D. J.; Williamson, B.; M cMillan, G. P. The interaction in planta of polygalacturonase from Botrytis cinerea with a cell wall-bound polygalacturonase-inhibiting protein (PGIP) in raspberry fruits. J. Exp. Bot. 45:1837-1843; 1994.

Klee, H.; Horsch, R.; Rogers, S. Agrobacterium-mediated plant transformation and its further applications to plant biology. Annu. Rev. Plant Physiol. 38:467-486; 1987.

Klein, T. M.; A rentzen, R.; Lewis, P. A., et al. Transformation of microbes, plants and animals by particle bombardment. BioTechnology 10:286-291; 1992.

Klein, T. M.; Fromm, M. E.; Gradziel, T., et al. Factors influencing gene delivery into Zea mays cells by high velocity microprojectiles. BioTechnology 6:559-564; 1988.

Kung, S. D. Introduction: from hybrid plants to transgenic plants. Kung, S. D.; $W u, R$. Transgenic plants, engineering and utilization. San Diego, CA: A cademic Press; 1993:1:1-12.

Levin, M.; Strauss, H. S. Overview of risk assessment and regulation of environmental biotechnology. Risk assessment in genetic engineering. New Y ork: McGraw-Hill; 1993.

Lichtenstein, C. P.; Fuller, S. L. Vectors for the genetic engineering of plants. Genetic Engineering. London: A cademic Press; 1987.

Lindsey, K.; Jones, M. G. K. Plant biotechnology in agriculture. Milton Keynes, UK: Open University Press; 1989.

Maliga, P., Maliga, Z.S., Method for stably transforming plastids of multicellular plants. US Pat. No. 5, 451, 513; 1995.

Maniatis, T.; Goodbourn, S.; Fischer, J. A. Regulation of inducible and tissue-specific gene expression. Science 236:1237-1245; 1987.

Matzke, M. A.; Matzke, A. J. M. How and why do plants inactivate homologous (trans)genes? Plant Physiol. 107:679-685; 1995.

MCD onald, D. The ICRISAT approach to research on the groundnut aflatoxin problem. Proc. Int. Workshop on aflatoxin contamination of groundnut. Patancheru, India: ICRISA T: 317-321; 1989.

Meyer, P. Variation of transgene expression in plants. Euphytica 85:359366; 1995.

Meyer, P.; Walgenbach, E.; Bussmann, K., et al. Synchronized tobacco protoplasts are efficiently transformed by DNA. Mol. Gen. Genet. 199:269-276; 1985

Miller, F., Muller, N., Monk, R., et al. Breeding photoperiod insensitive sorghums for adaptation and yield. In: Proc. Int. Conf. Genet. Improvement of sorghum and pearl millet. Lubbock, TX: INTSORMIL Publ. No. 97-5; 1997:59-70.

Miller, J. S.; Wesley, S. V.; Naidu, R. A., et al. The nucleotide sequence of RNA-1 of Indian peanut clump furovirus. Arch. Virol. 141:23012312; 1996.

Moloney, M. M.; Walker, J. M.; Sharma, K. K. An efficient method for Agrobacterium-mediated transformation in Brassica napus cotyledon explants. Plant Cell Rep. 8:238-242; 1989.
Nene, Y. L. Multiple-disease resistance in grain legumes. Annu. Rev. Phytopathol. 26:203-217; 1988.

Nene, Y. L.; Reddy, M. V. Chickpea diseases and their control. Saxena, M. C.; Singh, K. B. The chickpea. Wallingford, UK: CAB International; 1987:233-270

Okada, K.; Takebe, I.; Nagata, T. Expression and integration of genes introduced into highly synchronized plant protoplasts. Mol. Gen. Genet. 205:398-403; 1986.

Ortiz, R., Critical role of plant biotechnology for the genetic improvement of food crops: perspectives for the next millennium. Electron. J. Biotechnol. 1:1998, http://www.ejb.org/content/vol1/issue3/full/7/.

Paszkowski, J., Potrykus, I., Hohn, B., et al., Transformation of hereditary material in plants. US Pat. N o. 5,453,367; 1995.

Peterson, G.C., Reddy, B.V.S., Y oum, O., et al., Breeding for resistance to foliar and stem-feeding insects of sorghum and pearl millet. In: Proc. Int. Conf. Genet. Improvement of sorghum and pearl millet. Lubbock, TX: INTSORMIL Publ. No. 97-5 (1997) 281- 302.

Potrykus, I. Gene transfer to plants: assessment and perspectives. Physiol. Plant 79:125-134; 1990.

Potrykus, I. Gene transfer to plants: Assessment of published approaches and results. Annu. Rev. Plant Physiol. Mol. Biol. 42:205-225; 1991.

Potrykus, I.; Shillito, R. D. Protoplasts: isolation, culture and plant regeneration. Methods Enzymol. 118:459-578; 1989.

Rai, K.N., A nand Kumar, K., Andrews, D.J ., et al., Breeding pearl millet for grain yield and stability. In: Proc. Int. Conf. Genet. Improvement of sorghum and pearl millet. Lubbock, TX: INTSOR MIL Publ. N 0. 97-5 (1997) 71-83.

Reddy, D. V. R. Groundnut viruses and virus diseases: distribution, identification and control. Annu. Rev. Plant Pathol. 70:665-678; 1991.

Reddy, M. V.; Sharma, S. B.; Nene, Y. L. Pigeonpea: disease management Nene, Y. L.; Hall, S. D.; Sheila, V. K. The pigeonpea. Wallingford, UK: CA B International; 1990:303-347.

Reddy, M. V.; Sheila, V. K. Phytophthora blight of pigeonpea: present status and future priorities. Int. J. Pest Manag. 40:98-102; 1994.

Reed, W.; Cardona, C.; Sithanantham, S., et al. The chickpea insect pests and their control. Saxena, M. C.; Singh, K. B. The chickpea. Wallingford, UK: CAB International; 1987:282- 318.

R eichel, C.; Mathur, J .; Eckes, P., et al. Enhanced green fluorescence by the expression of an Aequorea victoria green fluorescent protein mutant in mono- and dicotyledonous plant cells. Proc. Natl. Acad. Sci. USA 93:5888- 5893; 1996.

Reiss, B.; Sprengel, R.; Will, $H_{\text {., }}$ et al. A new sensitive method for quantitative and qualitative assay of neomycin phosphotransferase in crude cell extracts. Gene 30:211; 1984.

R oest, S.; Gilissen, L. J. W. Plant regeneration from protoplasts: a literature review. Acta Bot. Neerl. 38:1-23; 1989.

Sambrook, J.; Fritsch, E. F.; Maniatis, T. Molecular cloning: a laboratory manual. New Y ork: Cold Spring Harbour Press; 1989.

Sanford, J. C. Biolistic plant transformation. Physiol. Plant. 79:206-209; 1990.

Sanford, J.C., W olf, E.D., Allen, N.K., Method for transporting substances into living cells and tissues and apparatus therefor. US Pat. No. 4,954,050; 1990.

Sanford, J.C., Wolf, E.D., Allen, N.K., Biolistic apparatus for delivering substances into cells and tissues in a nonlethal manner. Aust. Pat. AU 621561; 1992.

Sasser, J. N.; Freckman, D. W. A world perspective on nematology: the role of society. Veech, J. A.; Dickson, D. W. Vistas on nematology: commemoration of the twenty-fifth anniversary of the Society of Nematologists. Hyattsville, MD: Society of Nematologists; 1987: 7-14.

Schibler, U.; Sierra, F. Alternative promoters in developmental gene expression. Annu. Rev. Genet. 21:237-257; 1987.

Schilperoort, R.A., Hoekama, A., Hooykas, P.J.J., Process for the incorporation of foreign DNA into the genome of dicotyledonous plants. US Pat. No. 4,940,838; 1990.

Scott, K. P.; Farmer, M. J.; Robinson, D. J., et al. Comparison of the coat protein of groundnut rosette assistor virus with those of other luteoviruses. Ann. Appl. Biol. 128:77-83; 1996.

Senthil, G.; Williamson, B.; Ramsay, G. Efficient transformation and regeneration of chickpea (Cicer arietinum). In: Proc. 15th EUCAR - 
PIA General Congress on Genetics and Breeding for Crop Quality and Resistance, 20-25 September, Viterbo, Italy; 1998.

Shanower, T. G.; Romeis, J.; Minja, E. M. Insect pests of pigeonpea and their management. Annu. Rev. Entomol. 44:77-96; 1999.

Sharma, K. K.; Anjaiah, V.; Moss, J. P. High frequency regeneration and transformation of peanut (Arachis hypogaea L.). Plant Physiol. 102:175; 1993a.

Sharma, K. K.; A njaiah, V.; Moss, J. P. Production of transgenic plants of groundnut (Arachis hypogaea L.) by Agrobacterium-mediated genetic transformation. Int. A rachis Newsl. 13:23-25; 1993b.

Sharma, K. K.; Bhojwani, S. S.; Thorpe, T. A. High frequency regeneration of shoots and roots from cotyledon explants of Brassica juncea (L.) Czern. Plant Sci. 66:247-253; 1990.

Sharma, S. B. Nematode diseases of chickpea and pigeonpea. Pulse pathology progress report No. 43. Patancheru, India: ICRISAT; 1985:1-103.

Sharma, S. B.; MCDonald, D. Global status of nematode problems of groundnut, pigeonpea, chickpea, sorghum and pearl millet, and suggestions for future work. Crop Prot. 9:453-458; 1990.

Sharma, S. B.; Remanandan, P.; Jain, K. C. Resistance to cyst nematode (Heterodera cajani) in pigeonpea cultivars and in wild relatives of Cajanus. Ann. Appl. Biol. 123:75-81; 1993a.

Sharma, S. B.; Singh, O.; Pundir, R. P. S., et al. Screening of Cicer species and chickpea genotypes for resistance to Meloidogyne javanica. Nematol. Medit. 21:165-167; 1993b.

Singh, L.; Gupta, S. C.; Faris, D. G. Pigeonpea: breeding. Nene, Y. L.; H all, S. D.; Sheila, V. K. The pigeonpea. Wallingford, UK: CAB International; 1990:375-399.

Singh, S. D.; King, S. B.; Werder, J. Downy mildew disease of pearl millet. Information Bulletin No. 37. Patancheru, India: ICR ISAT; 1993:1- 30.

Skoog, F.; Miller, C. O. Chemical regulation of growth and organ formation in plant tissues cultured in vitro. Symp. Soc. Exp. Biol. 11:118-131; 1957.

Stam, M.; Mol, J. N.; K ooter, J. M., et al. The silence of genes in transgenic plants. Ann. Bot. 79:3-12; 1997.
Stenhouse, J.W.; Bandyopadhyay, R.; Singh, S.D., et al., B reeding for grain mold resistance in sorghum. In: Proc. Int. Conf. Genet. Improvement of sorghum and pearl millet. Lubbock, TX: INTSORMIL Publ. No. 97-5; 1997:326-336.

Subrahmanyam, P.; Hildebrand, G. L.; Naidu, R. A., et al. Sources of resistance to groundnut rosette disease in global groundnut germplasm. Ann. A ppl. Biol. 132:473-485; 1998.

Taliansky, M. E.; Ryabov, E. V.; Robinson, D. J. Two distinct mechanisms of transgenic resistance mediated by groundnut rosette virus satellite RNA sequences. Mol. Plant- Microbe Interact 11:367- 374; 1998.

Thakur, R.P.; Frederiksen, R.A.; Murty, D.S., et al. Breeding for disease resistance in sorghum. In: Proc. Int. Conf. Genet. Improvement of sorghum and pearl millet. Lubbock, TX: INTSORMIL Publ. No. 975; 1997:303-315.

Vaucheret, $H_{\text {.; }}$ Beclin, C.; Elmayan, T., et al. Transgene-induced gene silencing in plants. Plant J 16:651-659; 1998.

Wesley, S. V.; Mayo, M. A.; Jolly, C. A., et al. The coat protein of Indian peanut clump virus: relationships with other furoviruses and with barley stripe mosaic virus. Arch. Virol. 134:271-278; 1994.

Wightman, J. A.; Ranga Rao, G. V. Groundnut insects. Smartt, J. The groundnut crop. London: Chapman I.B.H.; 1999:317-336.

Wilmink, A.; Dons, J. J. M. Selective agents and marker genes for use in transformation of monocotyledonous plants. Plant Mol. Biol. Rep. 11:165-185; 1993.

Yadav, O. P.; Weltzien R. E. Breeding for adaption to abiotic stresses. In: Khairwal, I. S.; Rai, K. N.; Andrews, D. J., et al., eds. Pearl millet breeding. New Delhi: Oxford \& I.B.H.; 1999:317-336.

Zambryski, P. C. Basic processes underlying Agrobacterium-mediated DNA transfer to plant cells. Annu. Rev. Genet. 22:1-30; 1988.

Zambryski, P. C. Chronicles from the Agrobacterium-plant cell DNA transfer story. Annu. Rev. Plant Physiol. Plant Mol. Biol. 43:465490; 1992.

Zambryski, P.; Tempe, J.; Schell, J. Transfer and function of T-DNA genes from A grobacterium Ti and Ri plasmids in plants. Cell 56:193-201; 1989. 